\title{
CRITERIOS FORMALES PARA LA PRESENTACIÓN Y PUBLICACIÓN DE ORIGINALES $r_{e}$ ALA
}





\section{Criterios formales para la presentación y publicación de originales}

\section{TEMAS DE INTERÉS}

La Revista de Estudios de la Administración Local y Autonómica (REALA) publica trabajos originales sobre temas relacionados con la Administración local y autonómica y lo hace con un carácter multidisciplinar, especialmente en aquellas ciencias sociales que contribuyen a la comprensión del objeto de la revista: derecho, ciencia de la administración, ciencia política, gestión pública, sociología y economía.

Excepcionalmente se aceptarán trabajos relevantes ya publicados, siempre y cuando representen una contribución importante al conocimiento en las áreas de la REALA, y su publicación previa se haya producido en una lengua no española.

Las “Experiencias y Casos" deberán informar sobre innovaciones, nuevas aportaciones, debates en curso, hallazgos singulares en la Administración española y extranjera y sólo en estos casos se puede justificar su publicación sin la extensión y desarrollo teórico o el detalle analítico requerido a otros artículos, así como sin una extensa bibliografía.

\section{ENVÍO DE ORIGINALES}

Los originales, que deberán ser inéditos, se enviarán escritos en Microsoft Word o en formato compatible. Se pueden hacer llegar por correo electrónico a la dirección de la Secretaría de la revista.

\section{FORMATO}

Los originales deberán ir escritos a espacio y medio, en letra Times New Roman tamaño 12. La extensión total no deberá superar las 30 páginas (10.000 a 12.000 palabras), incluidos notas a pie de página, bibliografía y apéndices en su caso. Los gráficos, tablas y otros dibujos e imágenes deberán integrarse dentro del texto e ir numerados consecutivamente. La primera página incluirá el título, nombre del autor o autores, filiación académica o profesional, direcciones de correo ordinario y electrónico y teléfono de contacto. En una segunda página se presentarán dos resúmenes, en español e inglés, de un máximo de 150 palabras cada uno y entre tres y cinco palabras clave (en los dos 
idiomas). Se acompañará también un breve currículum vitae del autor o autores, con una extensión máxima de 8 a 10 líneas incluidas referencias bibliográficas.

\section{NORMAS DE EDICIÓN}

a) Bibliografía. Las referencias bibliográficas, que se limitarán a las obras citadas en el trabajo, se ordenarán alfabéticamente por el primer apellido, en mayúsculas, del autor, bajo el título "Bibliografía” y al final del original. Ejemplo:

LÓPEZ LÓPEZ, Juan (2005): “La reforma de la Constitución”, Revista de Estudios Políticos, $n^{\circ} 80$, pags. 20-35.

PÉREZ PÉREZ, Luis (2005): “La convalidación de los actos administrativos”, Revista de Administración Pública, nº 151, págs. 9-30.

LÓPEZ LÓPEZ, Juan (2004): Derecho Constitucional, Madrid, CEPC.

Si se citan dos o más obras de un determinado autor publicadas en el mismo año, se distinguirán por medio de una letra. Ejemplo: LÓPEZ LÓPEZ (2005a) y LÓPEZ LÓPEZ (2005b).

b) Notas a pie de página. Todas las notas irán a pie de página, numeradas mediante caracteres arábigos y en formato superíndice. No se incluirán las referencias bibliográficas completas, sino solamente su forma abreviada. Ejemplo: LÓPEZ LÓPEZ (2005): 90.

c) Citas. Las citas irán entrecomilladas. Si exceden de tres líneas irán separadas del cuerpo principal del texto, sangradas y a espacio sencillo. Cualquier cambio introducido en la cita original deberá indicarse encerrándolo entre corchetes.

\section{PROCESO DE PUBLICACIÓN}

La Revista de Estudios de la Administración Local y Autonómica acusará recibo de todos los originales en el plazo de treinta días desde su recepción. El Consejo de Redacción decidirá la publicación de los trabajos sobre la base de dos informes de evaluación, emitidos por sendos especialistas ajenos a la organización editorial de la revista, aplicándose el método doble anónimo. La publicación podrá quedar condicionada a la introducción de cambios con respecto a la versión original motivada por el resultado de las evaluaciones. En este caso, los autores dispondrán de dos semanas para comunicar a la Secretaría de la revista si acceden a realizar tales modificaciones en el sentido propuesto por el Consejo Editorial, así como el plazo en el que se comprometen a entregar la versión revisada, que en ningún caso será superior

322 a un mes. La decisión sobre la publicación no excederá de seis meses. Los autores de 
artículos aceptados para publicación podrán ser requeridos para la corrección de pruebas de imprenta, que habrán de ser devueltas en el plazo de 48 horas. No se permitirá la introducción de cambios sustanciales en las pruebas, quedando éstos limitados a la corrección de errores con respecto a la versión aceptada.

\section{DERECHOS Y OBLIGACIONES DE LOS AUTORES}

Los autores/as que propongan manuscritos para su publicación en la revista tienen los siguientes derechos:

1. A recibir acuse de recibo, por correo electrónico, de sus comunicaciones con la Secretaría de la REALA, especialmente en lo que se refiere al envío del manuscrito y materiales complementarios.

2. A que la Secretaría de la revista mantenga el anonimato de su autoría y no difunda su manuscrito más allá de lo necesario para el proceso de evaluación.

3. A formular quejas y reclamaciones mediante escrito dirigido a la Secretaría de la revista, de las que también recibirá acuse de recibo por correo electrónico.

4. A recibir una respuesta motivada sobre la decisión final del Consejo Editorial, salvo en el caso de los manuscritos rechazados en la selección previa.

Los autores/as tienen las siguientes obligaciones:

1. El envío de un manuscrito a la REALA supone la lectura y aceptación de las normas editoriales y las instrucciones a los autores de la revista.

2. Mientras el manuscrito esté en proceso de evaluación por parte de la revista, los autores/as no lo presentarán, para su evaluación, a otras revistas. Para ello adjuntarán al texto una declaración formal en la que deben hacer constar que el contenido esencial del mismo no ha sido publicado ni se va a publicar en ninguna otra obra o revista mientras esté en proceso de evaluación.

3. Los autores/as se comprometen a no publicar su artículo en ninguna otra revista, sea en formato de papel o electrónico, salvo que la REALA les autorice expresamente a hacerlo.

\section{COPYRIGHT}

Es condición para la publicación que el autor o autores ceda(n) a la Revista, en exclusiva, los derechos de reproducción. Si se producen peticiones de terceros para reproducir o traducir artículos o partes de los mismos, la decisión corresponderá al INAP. 


\section{ADVERTENCIA}

Cualquier incumplimiento de las presentes Normas constituirá motivo para el rechazo del original remitido.

Secretaría de la Revista de Estudios de la Administración Local y Autonómica Departamento de Publicaciones, Estudios y Documentación Instituto Nacional de Administración Pública

C/ Atocha, 106. 28012 MADRID

Teléfono: (91) 2739119. FAX: (91) 2739287

Correo electrónico: reala@inap.es 